\author{
Ю. С. Олефір
}

Луганський науково-дослідний експертно-

криміналістичний иентр МВС України

Yu. Olefir

Luhansk Scientific Research Forensic Center, MIA of Ukraine

\title{
МОЖЛИВОСТІ СУДОВОЇ ТОВАРОЗНАВЧОЇ ЕКСПЕРТИЗИ В МЕЖАХ КРИМІНАЛЬНОГО ПРОВАДЖЕННЯ
}

\author{
THE OPPORTUNITIES OF MERCHANDISING FORENSIC \\ EXAMINATION WITHIN THE CRIMINAL PROCEEDINGS
}

\begin{abstract}
Мета статті - окреслити особливості призначення і проведення судової товарознавчої експертизи в межах кримінальних проваджень, пов'язаних, зокрема, із привласненням, розтратою майна або заволодінням ним, крадіжками, одержанням неправомірної вигоди тощо. У процесі дослідження уточнено предмет, об’єкт, завдання судової товарознавчої експертизи, окреслено загальні принципи побудови методики її проведення. Узагальнено перелік питань, які ставлять на вирішення судової товарознавчої експертизи. Запропоновано приклад (з експертної практики), у якому висвітлено можливості судової товарознавчої експертизи з вирішення завдань у межах кримінального провадження за фактом отримання неправомірної вигоди. Обгрунтовано необхідність призначення судової товарознавчої експертизи в межах кримінальних проваджень щодо крадіжок майна, одержання неправомірної вигоди, виготовлення недоброякісної продукції, позовів про відшкодування шкоди за ушкодження майна при аварійних ситуаціях, пожежах тощо, розглянуто iï можливості. Достовірність отриманих результатів і висновків забезпечено загальнонауковими і спеціальними методами пізнання, зокрема: системно-структурним з'ясовано сутність досліджуваних категорій і правових явищ, їх елементно-компонентний склад; науковою абстракцією сформульовано позиції щодо оцінки теоретичних, правових та організаційних засад проведення судової товарознавчої експертизи в межах кримінального провадження; логіко-аргументаційним проаналізовано чинні нормативні положення щодо їх повноти; догматичний сприяв поглибленню та уточненню понятійно-категоріального апарату дослідження; метод моделювання - формулюванню висновків щодо можливостей судової товарознавчої експертизи в межах кримінального провадження.
\end{abstract}

Ключові слова: судово-експертна діяльність; судова товарознавча експертиза; товар; спеціальні знання; експерт; товарознавчі знання.

Цель статьи - раскрыть особенности назначения и проведения судебной товароведческой экспертизы в рамках уголовных производств, связанных, в частности, с присвоением, растратой имущества или завладением им, кражами, получением неправомерной выгоды и т. п. В процессе исследования уточнены предмет, объект, задачи судебной товароведческой экспертизы, определены общие принципы построения методики ее проведения. Обобщен перечень вопросов, которые ставят на решение судебной товароведческой экспертизы. Предложен пример (из экспертной практики), в котором освещены возможности судебной товароведческой экспертизы по решению задач в рамках уголовного производства по факту получения неправомерной выгоды. Обоснована необходимость назначения судебной товароведческой экспертизы в рамках уголовных производств по кражам имущества, получения неправомерной выгоды, изготовления недоброкачественной продукции, исков о возмещении вреда за повреждение имущества при аварийных ситуациях, пожарах и т. д., рассмотрены ее возможности. Достоверность полученных результатов и выводов обеспечена общенаучными и специальными методами познания, в частности: системно-структурным раскрыта сущность исследуемых категорий и правовых явлений, их элементно-компонентный состав; научной абстракцией сформулированы позиции по оценке теорети- 
ческих, правовых и организационных основ проведения судебной товароведческой экспертизы в рамках уголовного производства; логико-аргументационным проанализированы действующие нормативные положения касательно их полноты; догматический способствовал углублению и уточнению понятийно-категориального аппарата исследования; метод моделирования - формулированию выводов относительно возможностей судебной товароведческой экспертизы в рамках уголовного производства.

Ключевые слова: судебно-экспертная деятельность; судебная товароведческая экспертиза; товар; специальные знания; эксперт; товароведческие знания.

The purpose of the article is to outline the peculiarities of commissioning and conducting of forensic commodity expertise within the framework of criminal proceedings related to misappropriation or embezzlement of property, its plunder, deriving of improper advantage, etc. In the course of the research there were specified the subject, the object, and the task of forensic commodity examination; were outlined general principles of its conduction and methodic. The list of topical issues that are raised with the commodity examination was summarized. The author provides an example (from expert practice), which illustrates the possibilities of forensic commodity expertise in solving issues within the framework of criminal proceeding upon the deriving of improper advantage. The potential and the necessity of forensic expertise commissioning within the framework of criminal proceedings upon the embezzlement of property, deriving of improper advantage, production of defective goods and within the framework of claims for compensation for property damage in case of emergency, fire, etc. were substantiated by the author. The reliability of the obtained results and conclusions is ensured by the use of the following system of scientific knowledge methods: system-structural method (using this method, the author has clarified the nature of the researched categories and legal phenomena, and their element-component structure); method of scientific abstraction (this method helped to formulate attitude towards the assessment of theoretical, legal and organizational foundations of conducting forensic commodity examination within the framework of criminal proceedings); logical argumentation method (using this method, the author analyzed current statutory regulations on their completeness); dogmatic method contributed to the extending and specifying of the conceptual and categorical framework of research; simulation method helped to draw conclusions regarding the possibilities of forensic commodity examination within criminal proceedings.

Keywords: forensic activity; forensic commodity examination/expertise; goods; specific knowledge; commodity expert; commodity knowledge.

Обов’язкова ознака об’єктивної сторони злочинів із матеріальним складом - причинний зв'язок між діянням і суспільно небезпечними наслідками (якщо такого немає, то виключається й кримінальна відповідальність за настання суспільно небезпечних наслідків) (Veresha, 2012). Важливу роль у розслідуванні таких і будь-яких інших кримінальних правопорушень відіграють висновки експертів за результатами проведення судових експертиз, що є вагомими джерелами доказів у кримінальному судочинстві.

Проте слідчі та судді не завжди повною мірою усвідомлюють можливості судової експертизи, особливо такого їі різновиду, як судова товарознавча (далі - СТЕ), що й засвідчує актуальність обраної тематики. Це твердження підкріплюється перспективністю судової експертизи, зумовленою постійним розвитком наукових знань і відповідно методів дослідження, їх технічного та методологічного забезпечення.

Актуальність дослідження можливостей СТЕ, доводять результати аналізу експертної практики, підсилюється ще й наявністю певних проблем при встановленні причинно-наслідкових зав'язків як через помилки експертів, так і некваліфіковані формулювання запитань стосовно причин настання суспільно небезпечних наслідків, які ставлять слідчі на вирішення цієї експертизи.

Різні аспекти призначення СТЕ в кримінальному провадженні досліджували, зокрема, В. В. Архіпов, М. Я. Гавриляк, Л. І. Георгієв, Г. В. Дашков, М. С. Корчан, О. В. Оснач, І. А. Петрова, М. О. Подольний, М. О. Полякова, Р. Д. Рахунов, І. В. Сіроман, С. С. Толмачова, В. Г. Федоров, О. В. Целуйко. Проте збільшення потреб у здійсненні таких експертиз 
під час розслідування кримінальних правопорушень визначає доцільність подальшого грунтовного дослідження їх можливостей у межах кримінальних проваджень.

Метою статті є окреслення особливостей призначення і проведення СТЕ в межах кримінальних проваджень, пов'язаних, зокрема, із привласненням, розтратою майна або заволодінням ним, крадіжками, одержанням неправомірної вигоди тощо.

Судова експертиза («дослідження на основі спеціальних знань у галузі науки, техніки, мистецтва, ремесла тощо об’єктів, явищ і процесів з метою надання висновку 3 питань, що є або будуть предметом судового розгляду» (Pro sudovu ekspertyzu, 1994, st. 1) являє собою слідчу дію, під час якої особа, що володіє спеціальними знаннями, досліджує виявлені в межах розслідування матеріали і надає висновок із питань, які мають значення для кримінального провадження (Ekspertyzy u sudochynstvi, 2015). Порядок залучення експерта до проведення судової експертизи визначений Кримінальним процесуальним кодексом України (Kryminalnyi protsesualnyi kodeks, 2012). Тактичні рекомендації з призначення експертизи широко висвітлено в літературі з криміналістики (див., зокрема, Arkhipov, 2008; Havryliak, 2012; Tseluiko, 2013).

Висновок експерта за результатами дослідження наданих йому об'єктів і матеріалів $є$ самостійним джерелом доказів.

Процес експертного дослідження грунтується на використанні апробованих експертною практикою методів і методик. Обставини і факти, встановлені під час судової експертизи, мають бути науково обгрунтовані, що зумовлено змістом судової експертизи, яка спирається на використання спеціальних знань, тобто наукові знання, реалізовані в методиках судово-експертних досліджень (Pro sudovu ekspertyzu, 1997).

Об’єктами судових товарознавчих досліджень $є$ різноманітні товари, за винятком нерухомого майна (земельних ділянок, будівель, споруд).

Призначають СТЕ в разі, коли під час розслідування та судового розгляду в межах кримінальних, цивільних, арбітражних проваджень і проваджень у справах про адміністративні правопорушення постає потреба в спеціальних знаннях у галузі товарознавства. У кримінальних провадженнях, відкритих за фактами крадіжок майна, одержання неправомірної вигоди, виготовлення недоброякісної продукції, позовів про відшкодування шкоди за ушкодження майна при аварійних ситуаціях, пожежах тощо, СТЕ проводять державні спеціалізовані установи, перелік яких окреслено ст. 7 Закону України «Про судову експертизу».

CTE, грунтуючись на знаннях у галузі товарознавства, активно «запозичує» інженерно-технічні та інженерно-економічні знання. Сьогодні ця експертиза належить до таких, що розвиваються, а отже ії науково-методична база потребує подальшого вдосконалення.

Головне завдання СТЕ - визначення фактичної якості, цінності виробів (товарів) за результатами дослідження їх товарних (споживчих) властивостей. Значну увагу при цьому приділяють стану конкретних товарів у певний проміжок часу та їх вартості і споживчій вартості (Ekspertyzy u sudochynstvi, 2015, s. 207).

Завданнями СТЕ також є й пов’язані зі встановленням:

відповідності/невідповідності продукції та їі фактичних характеристик якості (i відповідно вартості), комплектності вимогам стандартів та іншої технічної або супровідної документації, стандартам-зразкам, способу упакування, умов транспортування, зберігання, уцінки нормативним вимогам;

механізму зміни якості товару. 
Предмет дослідження визначається в кожному індивідуальному випадку залежно від цілей СТЕ і зазвичай стосується встановлення фактичних даних, які підтверджують або спростовують відповідність характеристик досліджуваних об'єктів товарного походження базовим (нормативним) значенням, а також обставин, що сприяли зниженню якості (цінності) товару (недотримання умов зберігання, транспортування, правил упакування, розбракування і уцінки товару) (Havryliak, 2012, s. 36).

Об'єктом СТЕ $є$ різні вироби товарного походження, зразки, матеріали кримінального провадження, у яких зазначені товарні характеристики досліджуваних об’єктів та інша інформація про зміну їх споживчих (вартісних) властивостей. До об'єктів СТЕ належать меблеві, будівельні, косметичні, галантерейні, канцелярські товари, одяг, взуття, побутова техніка, фото-, радіо- та відеоапаратура і матеріали, обчислювальна техніка, ювелірні вироби тощо. Тобто об’єктами такої експертизи можуть бути товари, які мають споживчі якості та певну ціну (Ekspertyzy u sudochynstvi, 2015, s. 208).

Загальна методика проведення СТЕ побудована на зіставленні встановлених за допомогою візуальних та інструментальних методів (способів) ознак тих властивостей та особливостей об’єкта, які мають практичне значення для вирішення поставленого завдання (Romaniuk, 2002, s. 86). Під час CTE зазвичай послуговуються спеціальними методами дослідження, запозиченими з таких галузей промисловості, як текстильна, харчова, легка, важке машинобудування, а також галузей науки, як-то матеріалознавство, криміналістична наука, що докладно висвітлені в міжнародних, національних і галузевих стандартах, технічних умовах, правилах, нормах, положеннях, інструкціях, рекомендаціях, переліках, настановних документах Держспоживстандарту України тощо (Pro zatverdzhennia Instruktsii, 1998). При цьому методи та методики, застосовувані в процесі судової експертизи (розроблені криміналістичною наукою, методи проектування, модифікування, ремонту виробів товарного походження, діагностики прихованих у них дефектів і наявних пошкоджень, реєстраційні та розрахункові методи, у тому числі методи визначення різних видів зносу (фізичного, функціонального, економічного) тощо), мають бути адаптовані до потреб судочинства і рекомендовані для використання в експертній практиці.

Чи не найважливішим дослідженням у межах СТЕ $€$ порівняння безпосередньо встановлених характеристик об’єкта з визначеними в нормативно-технічній і супровідній документації, а також у стандарті-зразку. За відсутності зазначених документів та еталонів проведення порівняльного дослідження, так само як і виконання експертизи в цілому, неможливо.

У сучасних умовах потреба у СТЕ щороку зростає. Причому, засвідчує практика, більшість експертиз здійснюють у межах кримінальних проваджень. Найчастіше завданням СТЕ є визначення вартості досліджуваних об’єктів за матеріалами (документами), наданими на дослідження (Arkhipov, 2008).

В окремих випадках експерту надають:

висновки експертів інших спеціальностей;

протоколи огляду;

протоколи вилучення документів;

протоколи допитів;

пояснювальні та роз'яснювальні записки;

фотографії.

Судовий експерт, який проводить товарознавчу експертизу, відповідає на доволі широке коло запитань, які стосуються різних характеристик досліджуваного об'єкта 
(виробу, товару), сфери його застосування, стану об’єкта, чинників збереження об’єкта або обставин, що спричинили зниження його якості.

Проте, ставлячи експертові запитання, слід зважати на його компетенцію в галузі товарознавчої експертизи. Так, є певний перелік запитань, на які він не має права відповідати. Наприклад, чи належать дві частини тому самому об’єкту. Для встановлення таких фактів потрібні інші види експертиз із застосуванням матеріалознавчого або трасологічного аналізу. Товарознавець може визначити, чи належать досліджувані частини об’єкта одному виду виробів (певній моделі одягу, приміром).

Загалом на вирішення СТЕ можуть ставити такі запитання:

Яка товарна належність наданого на дослідження товару (виробу)?

Чи відповідає наданий на дослідження товар за своїми якісними показниками вимогам стандартів?

Чи відповідають (відповідали) умови зберігання і транспортування товару правилам, встановленим нормативно-технічною документацією? Якщо ні, то чи могло це призвести до зниження його якості (у подальшому до негативного впливу на здоров’я людини тощо)?

Чи відповідає упаковка товару вимогам стандартів? Якщо ні, то як могла вона вплинути на зниження якості товару?

Чи відповідають фактичні кількісні та якісні характеристики товару аналогічним показникам, зазначеним у договорі, супровідних документах, маркувальних позначеннях тощо? Якщо ні, то в чому ці відмінності?

Чи відповідають характеристики досліджуваного товару аналогічним показникам товару, наданого як зразок? Якщо ні, то в чому ці відмінності?

Який ступінь зниження якості наданого на дослідження товару з урахуванням його стану?

Якою була вартість наданого на дослідження товару на (дата)?

Призначення СТЕ за таким кримінальним правопорушенням, як одержання неправомірної вигоди (ст. 368 Кримінального кодексу України (Kryminalnyi kodeks, 2001) дає змогу встановити:

якісні та кількісні характеристики виробу;

групову належність, походження, спосіб і час виготовлення виробу;

вартість, фактичну роздрібну ціну виробу (товару).

Об’єктами дослідження в цьому разі є промислові товари та їх документація (Veresha, 2012).

СТЕ має відповісти на такі запитання:

Яким є найменування наданого на дослідження товару?

До якого виду, сорту, артикулу належить наданий на дослідження товар?

Якою $є$ вартість одиниці наданого на дослідження товару?

Якою є роздрібна ціна одиниці товару, що зазначена в товарно-транспортній накладній або рахунку-фактурі?

Приклад з експертної практики (вирішення завдань у межах кримінального провадження щодо отримання неправомірної вигоди за допомогою СТЕ). Під час огляду місця події за фактом отримання доцентом кафедри одного з університетів неправомірної вигоди від студента за іспит виявлено його розписку про надання спонсорської допомоги кафедрі університету в розмірі 10000 грн. Підозрюваний у процесі допиту пояснив, що на ці кошти придбав для кафедри металеві двері. 3 метою перевірки вер- 
сії підозрюваного слідчий призначив СТЕ, поставивши експертові запитання: «Якою $€$ вартість металевих дверей, встановлених на кафедрі в аудиторії № ...?».

Спираючись на результати експертизи, слідчий дійшов висновку про те, що частину коштів, отриманих як добровільний внесок, витрачено викладачем незаконно, на власні потреби (Pro sudovu ekspertyzu, 2010).

Висновки. Результати судової товарознавчої експертизи як однієї з форм застосування спеціальних товарознавчих знань сприяють одержанню доказової інформації в кримінальному провадженні, дозволяючи дійти обгрунтованого експертного висновку про вид, найменування, артикул, споживчі властивості, якість та інші характеристики товару, встановити їх стан і вартість у певний період часу. Особливостями таких експертиз є їх багатоетапність, зумовлена характером вирішуваних завдань, специфічними особливостями об’єктів дослідження, якими є багатокомпонентні події злочину.

\section{References}

Arkhipov, V. V. (2008). Sudovo-tovaroznavcha ekspertyza tovariv narodnoho spozhyvannia. Teoriia ta praktyka: navch.-prakt. posib. Kyiv: TsUL. 306 s.

Ekspertyzy u sudochynstvi Ukrainy. Roziasnennia. (2015). Biuleten zakonodavstva i yurydychnoi praktyky Ukrainy / za zah. red. V. H. Honcharenka, I. V. Hory. № 5-6. 506 s.

Havryliak, M. Ya. (2012). Metodychno-orhanizatsiini zasady provedennia tovaroznavchoi ekspertyzy. Naukovi zapysky. № 3. S. 36-39.

Kryminalnyi kodeks Ukrainy. № 2341-III. (2001). Uziato z https://zakon3.rada.gov.ua/laws/show/2341-14.

Kryminalnyi protsesualnyi kodeks Ukrainy. № 4651-VI. (2012). Uziato z https://zakon0.rada.gov.ua/laws/show/ $\mathrm{ru} / 4651-17$.

Pro sudovu ekspertyzu u kryminalnykh i tsyvilnykh spravakh: postanova Plenumu Verkhovnoho Sudu Ukrainy v kryminalnykh spravakh / [uporiad. Rozhnova V. V., Sizonenko A. S., Udalova L. D.]. (2010). Kyiv: Palyvoda A. V. S. $172-178$.

Pro sudovu ekspertyzu v kryminalnykh i tsyvilnykh spravakh: postanova Plenumu Verkhovnoho Sudu № 8. (1997). Uziato z https://zakon3.rada.gov.ua/laws/show/v0008700-97.

Pro sudovu ekspertyzu: zakon № 4038-KhII. (1994). Uziato z https://zakon.rada.gov.ua/laws/show/4038-12.

Pro zatverdzhennia Instruktsii pro pryznachennia ta provedennia sudovykh ekspertyz ta ekspertnykh doslidzhen ta Naukovo-metodychnykh rekomendatsii z pytan pidhotovky ta pryznachennia sudovykh ekspertyz ta ekspertnykh doslidzhen: nakaz Miniustu № 53/5. (1998). Uziato z https://zakon.rada.gov.ua/ laws/show/z0705-98.

Romaniuk, B. V. (2002). Suchasni teoretychni ta pravovi problemy vykorystannia spetsialnykh znan u dosudovomu slidstvi: monohrafiia. Kyiv: NAVS. $196 \mathrm{s.}$

Tseluiko, O. V. (2013). Pravove rehuliuvannia orhanizatsii sudovykh tovaroznavchykh ekspertyz ta ekspertnykh, tovaroznavchykh doslidzhen v Ukraini. Chasopys Kyivskoho universytetu prava. № 2. S. 122-126.

Veresha, R. V. (2012). Kryminalne pravo Ukrainy. Zahalna chastyna: navch. posib. Kyiv: TsUL. 320 s.

\section{Список використаних джерел}

Архіпов, В. В. (2008). Судово-товарознавча експертиза товарів народного споживання. Теорія та практика: навч.-практ. посіб. Київ: ЦУЛ. 306 с.

Експертизи у судочинстві України. Роз'яснення. (2015). Бюлетень законодавства і юридичної практики України / за заг. ред. В. Г. Гончаренка, І. В. Гори. № 5-6. 506 с.

Гавриляк, М. Я. (2012). Методично-організаційні засади проведення товарознавчої експертизи. Наукові записки. № 3. С. 36-39.

Кримінальний кодекс України. № 2341-III. (2001). Узято з https://zakon3.rada.gov.ua/laws/show/2341-14.

Кримінальний процесуальний кодекс України. № 4651-VI. (2012). Узято з https://zakon0.rada.gov.ua/laws/ show/ru/4651-17. 
Про судову експертизу у кримінальних і цивільних справах: постанова Пленуму Верховного Суду України в кримінальних справах / [упоряд. Рожнова В. В., Сізоненко А. С., Удалова Л. Д.]. (2010). Київ: ПАЛИВОДА А. В. С. 172-178.

Про судову експертизу в кримінальних і цивільних справах: постанова Пленуму Верховного Суду № 8 . (1997). Узято з https://zakon3.rada.gov.ua/laws/show/v0008700-97.

Про судову експертизу: закон № 4038-XII. (1994). Узято з https://zakon.rada.gov.ua/laws/show/4038-12.

Про затвердження Інструкції про призначення та проведення судових експертиз та експертних досліджень та Науково-методичних рекомендацій з питань підготовки та призначення судових експертиз та експертних досліджень: наказ Мін’юсту № 53/5. (1998). Узято з https://zakon.rada.gov.ua/laws/ show/z0705-98.

Романюк, Б. В. (2002). Сучасні теоретичні та правові проблеми використання спеціальних знань у досудовому слідстві: монографія. Київ: НАВС. 196 с.

Целуйко, О. В. (2013). Правове регулювання організації судових товарознавчих експертиз та експертних, товарознавчих досліджень в Україні. Часопис Київського університету права. № 2. С. 122-126.

Вереша, Р. В. (2012). Кримінальне право України. Загальна частина: навч. посіб. Київ: ЦУЛ. 320 с. 